\title{
Dispersal ability and invasion success of Crepidula fornicata in a single gulf: insights from genetic markers and larval-dispersal model
}

\begin{abstract}
The success of an exotic species relies on many factors including dispersal capabilities and adaptation to novel environments. In particular, rapid spread from an initial point of introduction favours long-term establishment of exotic species, especially when large genetic diversity is maintained during the colonization phase. We here focused on the slipper limpet, Crepidula fornicata, a species native to the western Atlantic that has successfully invaded European bays and estuaries since the end of the nineteenth century following repeated introductions. Its settlement at high densities has major consequences on the macro-benthic fauna and flora. The aim of the present study was to analyse the ability of C. fornicata for rapid diffusion and long-distance dispersal, at the level of a large French gulf, namely the gulf of St-Malo (covering $120 \mathrm{~km}$ in latitude and $40 \mathrm{~km}$ in longitude) in the English Channel. The genetic architecture of 16 populations distributed all over this gulf was investigated using five microsatellite loci. Genetic diversity was found to be high and did not vary significantly with population density, population age or geographic location. Moreover, despite potential isolation among populations due to a strong tidal regime and the
\end{abstract}

Communicated by K. Reise

F. Viard $(\square) \cdot$ L. Dupont

Evolution \& Génétique des Populations Marines, UMR ADMM 7144 CNRS-UPMC,

Station Biologique, Place Georges-Teissier, BP74 29682 ROSCOFF cedex, France

E-mail: viard@sb-roscoff.fr

Tel.: + 33-2-98292312

Fax: $+33-2-98292336$

C. Ellien

Département Milieux et Peuplements Aquatiques,

Museum National d'Histoire Naturelle, 61, Rue Buffon, 75005 Paris, France

Present address: L. Dupont

Citadel Hill, The Laboratory,

Marine Biological Association of the United Kingdom,

PL1 2PB Plymouth, UK action of wind-induced currents, only weak barriers to gene flow were found across the gulf. These results were in agreement with results obtained from a simple 2D larval dispersal model. Both genetic data and the simulation model highlighted the potential for rapid and efficient spread of $C$. fornicata at a regional level.

Keywords Slipper limpet · Invasive species · Larval dispersal $\cdot$ Gene flow $\cdot$ Microsatellite

\section{Introduction}

Out of the 104 exotic species that have been introduced along the French English Channel and Atlantic Coasts (Goulletquer et al. 2002), only few are invasive; Crepidula fornicata is one of these emblematic species. Native to the Western Atlantic coasts, this gastropod has been repeatedly introduced into Europe during the nineteenth and twentieth centuries (Blanchard 1997). Its introduction and spread in Europe has involved both primary and secondary introductions often due to imports and cultures of oysters (Wolff and Reise 2002). From their introduction in the 1970s, the French populations of $C$. fornicata quickly reached large densities (e.g. $214,000 \mathrm{t}$ in the bay of Mont-Saint Michel; Ehrhold et al. 1998). Consequently, C. fornicata has major consequences on the macro-benthic fauna and flora from species-to-species interaction up to more global effects on composition of benthic community [details and references in Thieltges et al. (2003)].

Invasion success is highly related to dispersal capabilities and adaptation to novel environments (Sakai et al. 2001). Sax and Brown (2000) recently pointed out various factors likely to favour the introduced species. Besides environmental changes or absence of parasites and predators, they evoked a mechanism defined by Williamson (1996) as the "propagule pressure hypothesis': propagules (i.e. seeds, spores, larvae) favour success of exotic species at different levels from local reinforcement of established populations to founding of new 
populations within the area of introduction. In this context, the occurrence of a long-lived larval stage in marine invertebrates can be a critical factor for the invasion process as larval dispersal may both favour the colonization of new habitats and strengthen existing populations by creating a demographic pressure. However, even in species with high dispersal capacity (i.e. long-lived planktonic stage), larval exchanges and subsequent gene flow between populations can be hampered (Borsa et al. 1994; Kyle and Boulding 2000; Pogson et al. 2001).

The aim of the present study was to investigate some facets of the propagule pressure hypothesis in relation to larval-dispersal ability over a regional scale of the European invader $C$. fornicata. In this context, population genetics is a helpful method as both high gene diversity and high gene flow are indicative of local reinforcement and rapid spread. In a previous study (Dupont et al. 2003), genetic diversity and structure was analysed in 12 French populations with eight enzymatic loci. High genetic diversity was observed in each of the 12 populations analysed as compared to populations from the native range of the species (i.e. Western Atlantic). However, as most samples were obtained from high-density populations, whether high levels of genetic diversity are general features of $C$. fornicata populations could not be investigated. Moreover, in Dupont et al. (2003), only one population per bay was analysed preventing fine-scale analyses of dispersal pattern. In the present study, we thus aimed at estimating the importance of effective dispersal and genetic diversity over a regional scale (i.e. a smaller scale than previously examined; Dupont et al. 2003). We analysed 16 populations (672 individuals) sampled in a large gulf, the Saint-Malo Gulf (SMG) which covers $120 \mathrm{~km}$ in latitude and $40 \mathrm{~km}$ in longitude. The SMG is located along the western coast of the Cotentin Peninsula in the English Channel where eddies potentially isolate populations located in different part of the Gulf (Fig. 1). Their genetic architecture was assessed with five microsatellite loci to address the following questions: (1) do these 16 populations exhibit contrasting patterns in terms of genetic diversity according to their density or location? (2) What is the degree of connectivity between populations over a regional scale? (3) Is effective larval dispersal hampered by known hydrodynamic features? To examine this last question, patterns of regional genetic structure were discussed in light of the results of a simple 2D-hydrodynamic model of larval dispersal.

\section{Material and methods}

Study area and sampling

The study area, the SMG, is located along the coast of the Cotentin Peninsula and limited by the Channel islands of Jersey and Guernsey (Fig. 1). The first occurrence of the slipper limpet in this area was reported in the 1970s (Ehrhold et al. 1998; Blanchard and Ehrhold 1999) in the Bay of Cancale (southern limit of the SMG) where extensive oyster and mussel cultures occur. This area is suitable for our investigation because (1) hydro-dynamic features and circular residual currents are well known (Orbi and Salomon 1988), (2) regular surveys of $C$. fornicata were carried out in particular in the southern part of the Gulf [e.g. side-scan sonar survey in 1996 in the bay of Cancale (Ehrhold et al. 1998)] and (3) a recent monitoring of benthic communities was carried out in the framework of the French National Program for Coastal Environment (2002). During this monitoring, specimens of $C$. fornicata were collected using a $0.25 \mathrm{~m}^{2}$ Hamon grab during the April and May 2002 BENTHOMONT cruises onboard of the "N.O. Côte de la Manche". Population density estimates were obtained by counting the number of chains (i.e. perennial stack of individuals, a typical characteristic of this species) onboard. The number of individuals was extrapolated based on the mean number of individuals per chain as obtained in two populations for which an extensive sampling was done (site 13 and 16 in Fig. 1; L. Dupont, D. Bernas and F. Viard, submitted). Sixteen populations (20-53 individuals per population) were selected in areas characterized by various population densities and potentially isolated by residual currents (Fig. 1). Based on hydrodynamic features, three groups were defined [A, B and C in Fig. 1; (Orbi and Salomon 1988)]. For each site, a sub-sample was preserved with $90 \%$ ethanol for genetic analyses.

Microsatellite loci genotyping and analyses

For all populations, except population 13 and 16 already analysed (L. Dupont, D. Bernas and F. Viard, submitted), total genomic DNA was extracted using the Nucleospin ${ }^{\circledR}$ Multi-96 Tissu Kit (MACHEREY-NAGEL). All the individuals were genotyped at five microsatellite loci: four, namely CfCA2, CfCA4, CfGT9 and CfGT14 as defined by Dupont and Viard (2003), and one (CfH7) newly developed locus (I. Kruse and F. Viard, unpublished data; forward and reverse primer sequences: F-5' GGTAACGTATTGCTACCGAAAG- ${ }^{\prime}$ and R-5'TCATGCGGGTTTGGTGG-3'). Loci [including $\mathrm{CfH} 7$ (annealing temperature of $54^{\circ} \mathrm{C}$ and $1.5 \mathrm{mM}$ of $\left.\mathrm{MgCl}_{2}\right)$ ] were amplified by polymerase chain reactions (PCR) following protocols detailed in Dupont and Viard (2003). PCR products were screened on a $6.5 \%$ polyacrylamide gel using a Li-Cor NEN Global IR2 DNA sequencer system.

The null hypothesis of independence between loci was tested from statistical genotypic disequilibrium analysis using Genepop v3.4 (Raymond and Rousset 1995). For each population, the genetic diversity was analysed by computing: allele frequencies, number of alleles $\left(N_{\text {all }}\right)$ and expected heterozygozity $\left(H_{\mathrm{e}}\right)$ using Genetix v 4.04 (Belkhir et al. 1996). To take into account variation in 


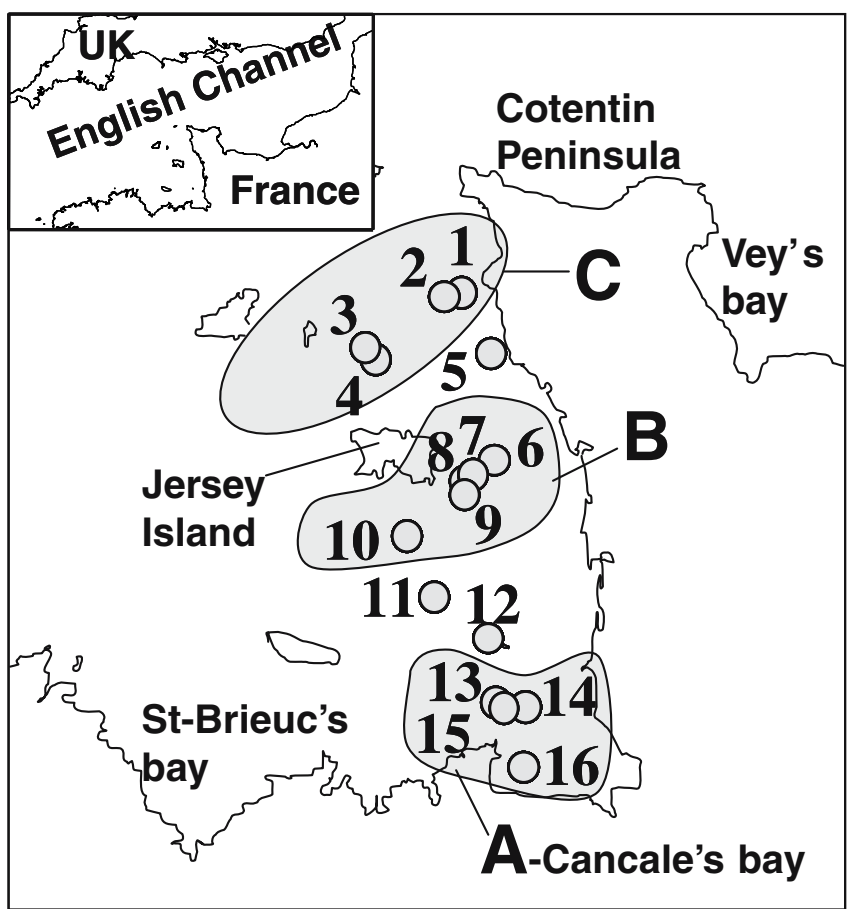

Fig. 1 Study area and location of sampling sites within the SaintMalo Gulf. Groups $A, B$ and $C$ refer to areas potentially isolated ( $C$ from either $A$ or $B$ ) due to circular currents (Orbi and Salomon 1988). The three groups are located in areas characterized by different densities of $C$. fornicata (as revealed by a survey of 75 stations sampled during the BENTHOMONT cruise, unpublished data): $A$ high density (54 stations: 8 without $C$. fornicata, 46 with up to 2,100 ind. $\mathrm{m}^{-2}$ ), $B$ low to medium density (16 stations: 4 without $C$. fornicata; 8 with $60-800$ ind. $\mathrm{m}^{-2}$ ), $C$ low density (17 stations: 12 without $C$. fornicata and 5 with 20 to 100 ind. $\mathrm{m}^{-2}$ ). See Table 1 for the density of populations analysed

sample size, allelic richness $\left[A_{\mathrm{r}}\right.$; El-Mousadik and Petit (1996)] was estimated using FSTAT v.2.9.3 (Goudet 1999). Tests for deviation from genotypic proportions expected under Hardy-Weinberg equilibrium were carried out using Genepop v3.4. The genetic structure between populations or groups was investigated by calculating the Weir and Cockerham's (1984) $\hat{\theta}$, an estimator of the fixation index $F_{\text {st }}$ with FSTAT. Because samples are not at Hardy-Weinberg equilibrium, tests for genetic differentiation were carried out using a $G$ test, as described by Goudet et al. (1996) and implemented in FSTAT. Tests for recent reduction or expansion of population effective size were carried out using the software BOTTLENECK (Cornuet and Luikart 1996) assuming an infinite-allele mutation model [see details in Dupont et al. (2003)].

\section{D-hydrodynamic Lagrangian model of larval dispersal}

We used a Lagrangian model to get a picture of potential and contemporary larval dispersal (density and location of larvae). Outputs of the model were summarized by building matrices of the number of larvae exchanged between each pair of populations. The hydrodynamic and larval transport models are detailed in Ellien et al. $(2000,2004)$. Briefly, the advection-dispersion numerical model used for this study simulates transport of planktonic particles on timescales ranging from days to years, under the influence of a hydrodynamic regime dominated by tide and wind forces. It is based on a hydrodynamic model for the English Channel, limits of which are $48^{\circ} 18^{\prime} \mathrm{N}$ and $51^{\circ} 20^{\prime} \mathrm{N}$ in latitude, $6^{\circ} 28^{\prime} \mathrm{W}$ and $3^{\circ} 00^{\prime} \mathrm{E}$ in longitude with a mesh size of one nautical mile (Salomon and Breton 1991). Instantaneous and residual velocities and trajectories for different tide and wind conditions are computed through the 'barycentric technique' [see details and references in (Ellien et al. 2004)]. Biological inputs in the model were as follows. C. fornicata is a perennial protandrous species with an extended breeding period from March to September (Dupouy and Latrouite 1979; Deslous-Paoli 1985). Larval dispersal was simulated over 21 days (i.e. larval life-span) corresponding to the freeswimming period of the pelagic veligers of $C$. fornicata (Coe 1949). As we were concerned with the scheme of potential larval dispersal and its relative differences among locations, the mortality term was set to zero. The location of larvae releases was chosen to fit exactly the location of each of the 16 populations for which genetic architecture was analysed (see above). Based on a female:male sex-ratio of 0.67:1 (Hoagland 1978) and estimated population density (Table 1), the stock of mature females was calculated. Given an average fecundity of 7,500 ovocytes per female [the lower bound for number of eggs per female (Coe 1949; Dupouy and Latrouite 1979)], the number of released larvae per square metre was assessed. Larval dispersal was first studied considering an average tide and no wind during the duration of larval life. Then, to investigate the influence of wind, three types of wind forcing corresponding to the main wind directions influencing the study area were applied in conditions of an average tide: constant winds from SW (i.e. direction $225^{\circ}$ ), NE (i.e. direction $45^{\circ}$ ) and NW (i.e. direction $315^{\circ}$ ) with a mean speed of $6 \mathrm{~m} \mathrm{~s}^{-1}$. Matrices of larval exchange were built for each wind condition and compared with Mantel tests using the module ISOLDE of Genepop v3.4 (Raymond and Rousset 1995).

\section{Results}

Overall microsatellite diversity and population diversity

Exact tests for genotypic linkage disequilibria between microsatellite loci within each population showed only five significant $P$ values out of 160 comparisons, i.e. a proportion comparable to that expected by chance alone. Across populations, none of the loci were found to be in linkage disequilibria. A high level of genetic diversity was observed over the whole study $(N=672$ individuals) with a total of 4, 24, 86, 61 and 18 alleles for CfCA2, CfCA4, CfGT9, CfGT14 and $\mathrm{CfH} 7$, respec- 
Table 1 Study population, model parameters and genetic diversity estimates across loci

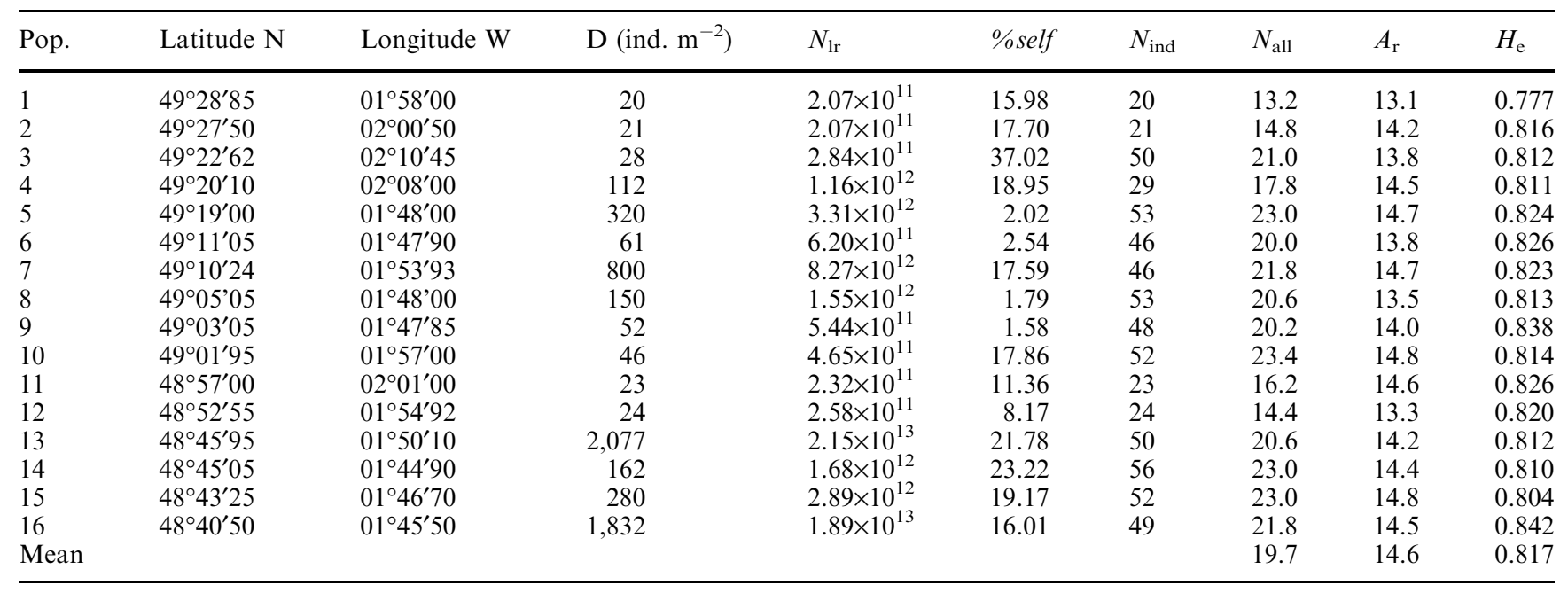

For each population, location of the sampling is indicated together with the estimated population density (D). $N_{\text {lr }}$ and $\%$ self are the estimated numbers of larvae released per population and the proportion of self-recruited larvae (number of larvae found to be at the location of their release compared to the number of larvae arrived in any of the other 15 populations at the end of the simulation run), respectively. The sampling size for genetic analysis $\left(N_{\text {ind }}\right)$ is given together with number of alleles $\left(N_{\text {all }}\right)$, allelic richness $\left(A_{\mathrm{r}}\right)$ and gene diversity $\left(H_{\mathrm{e}}\right)$

tively. Allelic frequencies are available upon request to the authors. Summary statistics describing the genetic diversity across loci within the 16 study populations are given in Table 1.

The mean number of alleles over loci was found to vary according to the population (from 13.2 to 23.4) but this was mainly due to a sampling size effect. Statistics taking into account for sampling size did not show such a variation: allelic richness was high whatever the population-varying from 13.1 to 14.8 - as was gene diversity - from 0.63 to 0.75 . Neither allelic richness (Pearson correlation coefficient, $r=0.24, n=16, P=0.36$ ) nor gene diversity (Pearson correlation coefficient, $r=0.27, n=16$, $P=0.31)$ were correlated with population density. Two populations, namely population 13 and 16 , exhibited the highest population density (Table 1). The lack of correlation between population density and allelic richness $(r=0.45, n=14, P=0.10)$ or gene diversity $(r=0.14$, $n=16, P=0.63)$ still held when these two particular populations were removed. Deviations from HardyWeinberg equilibrium were observed for all populations (Exact-test, $\left.P<10^{-3}\right)$. Out of the 16 study populations, only 4 (populations 5, 7, 9 and 16) showed evidence for a recent bottleneck or founding events; Wilcoxon onetailed test, $P=0.032$ ).

Genetic structure at the level of the Gulf

No genetic structure was revealed at the level of the whole gulf ( 16 populations, $\hat{\theta}=0.0000, P=0.203$ ) although a significant difference was found between groups $\mathrm{C}$ and $\mathrm{B}(\hat{\theta}=0.0017, P=0.033)$ and $\mathrm{A}$ and $\mathrm{B}$ $(\hat{\theta}=0.0013, P=0.017)$ but not $\mathrm{A}$ and $\mathrm{C}(\hat{\theta}=-0.0007$,
$P=0.467)$, as defined in Fig. 1. When considering each population pair, only 13 values of $\hat{\theta}$ out of $120(6.7 \%)$ were associated to a significant test. Most of them involved the population 6 ( 8 out of 13 comparisons) and to a lesser extent population 9 ( 3 out of 13 ). The particular situation of population 6 partly explained the genetic structure observed above between groups A, B and $\mathrm{C}$ : after removing population 6 , the genetic difference between groups $\mathrm{B}$ and $\mathrm{C}$ was maintained $(\hat{\theta}=0,001$, $P=0.017)$ but not between $\mathrm{A}$ and $\mathrm{B}(\hat{\theta}=0.0008$, $P=0.283)$.

\section{Larval dispersal mathematical modelling}

Mantel tests showed that matrices of larval exchanges simulated under various wind directions were highly correlated $(P<0.001)$. This pattern is likely to be due to the moderate value for wind speed used in the simulations; winds were not strong enough to modify the strong eddies (circular current) typical of the SMG. Relative larval exchanges among the 16 populations were thus found to be unaltered by wind conditions. Results with no wind are detailed below. The percentage of self-recruited larvae was found to be highly variable according to population (Table 1). When analysing the distribution of larvae after a 21-day period of dispersal, the largest proportion of larvae was found in receiving populations located in the vicinity of the population from which the larvae were released (Fig. 2). However, the model also gave evidence for the ability of larvae to be dispersed over large distances in particular for larvae released from the most southern locations (populations 13-16) to more northern locations (Fig. 3a). For 


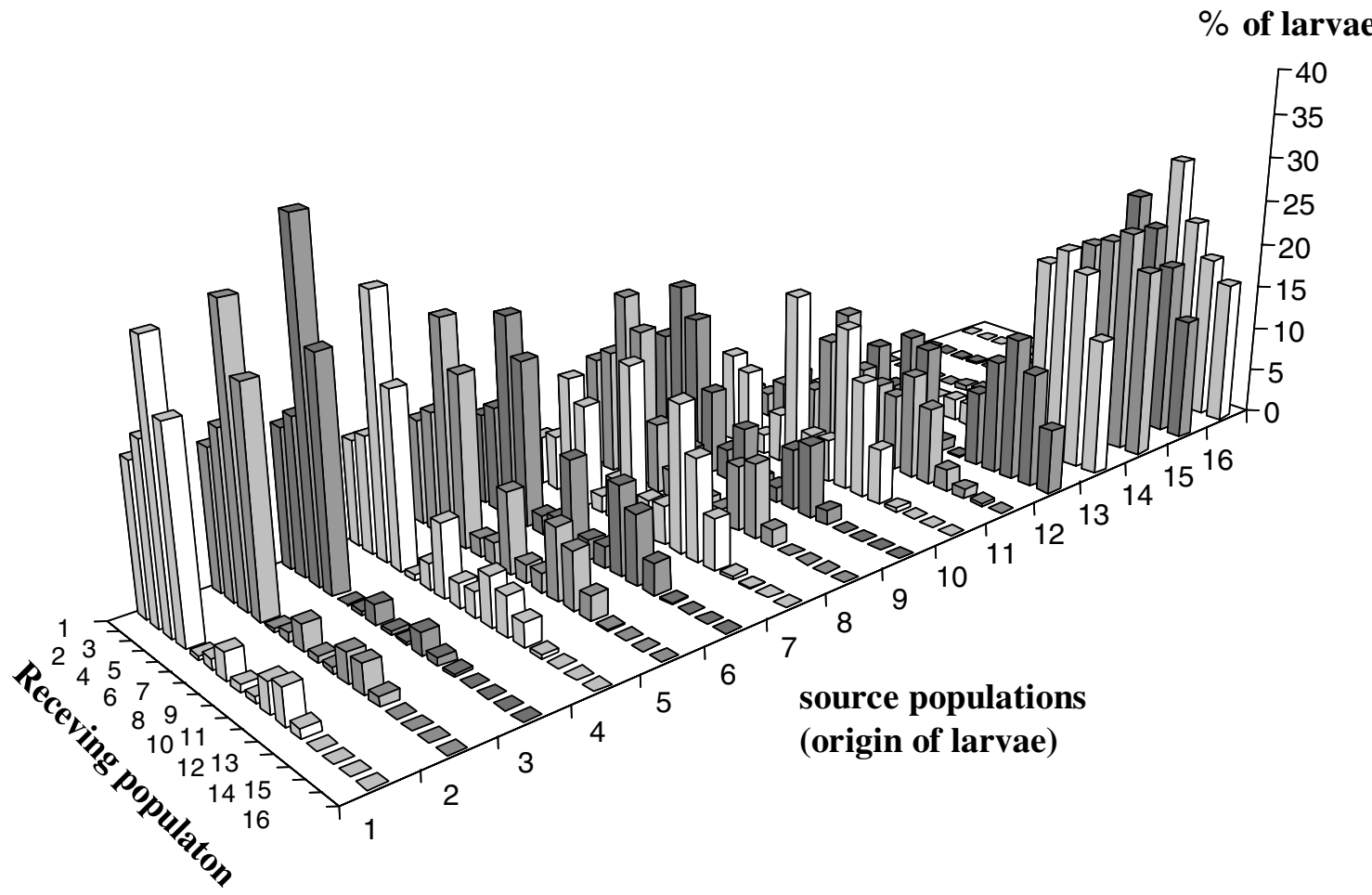

Fig. 2 Larval dispersal modelling: relative distribution of Crepidula fornicata larvae in each of the 16 populations after 21 days. For each source population, the percentage of larvae that are migrants (i.e. arriving in each of the 15 potential receiver populations) and selfrecruited is shown

instance, some of the larvae released from the most southern point (pop. 16) can reach the most northern populations (e.g. pop. 3, 4) after a 21-day period of dispersal (Fig. 3a). Conversely, larvae released from population 1 to 11 do not reach population 13-16. For example, larvae released from population 5 can reach the tip of the Cotentin Peninsula but do not enter the Bay of Cancale (Fig. 3a). Population density clearly has a strong effect to explain the observed patterns. For example, the low-density population 3 exhibited a much shorter dispersal distance compared to population 4 (Fig. 3b). No correlation was observed between genetic distance matrix (pairwise $\hat{\theta}$ values) and larval exchanges matrix (Mantel tests, $P=0.583$ ), a result due to almost unlimited gene flow among populations (see above).

\section{Discussion}

Dispersal is a critical factor for the success and sustainable settlement of introduced exotic species (Shigesada and Kawasaki 1997). Sessile marine invertebrates with long-lived pelagic larvae are expected to be efficient colonizers and to be able to spread rapidly over large distance (Pechenik 1999; Kinlan and Gaines 2003). Nevertheless, several studies have shown a lack of correlation between dispersal capability (as measured by the duration of the pelagic stage) and realized dispersal
(Borsa et al. 1994; Kyle and Boulding 2000; Pogson et al. 2001 and references therein). Dispersal ability can indeed be counter-balanced by various factors such as oceanographic processes (e.g. eddies, upwelling dynamics; Poulin et al. 2002) or biological features (e.g. gregariousness behaviour of larvae; Toonen and Pawlik 2001). Estimating realized dispersal distance thus requires multiple approaches (Swearer et al. 2002; Thorrold et al. 2002; Kinlan and Gaines 2003). Our study dealt with this issue in two ways: (1) by gathering genetic data to estimate effective dispersal which includes primary larval dispersal and secondary dispersal through migration of adults (i.e. human-mediated transport) and (2) by simulating larval dispersal taking into account oceanographic and biological features. Both approaches depicted the same situation: $C$. fornicata displays a high rate of larval exchanges between populations over a regional scale; the connectivity between populations in the SMG promoted rapid spreading (i.e. in less than 30 years) without a loss of genetic diversity during the colonization process.

Large dispersal distance as estimated from genetic data

Crepidula fornicata is thought to have invaded the SMG mainly through a South to North expansion from the Bay of Cancale where it was introduced in the 1970s with 
Fig. 3 Larval dispersal modelling: spatial distribution of Crepidula fornicata larvae released from a population 5 and 16 (which illustrate overlapping distribution) and b populations 3 and 4 (which illustrate density effects). Distribution and density of larvae are indicated; dots refer to location of the 16 study populations (Fig. 1)
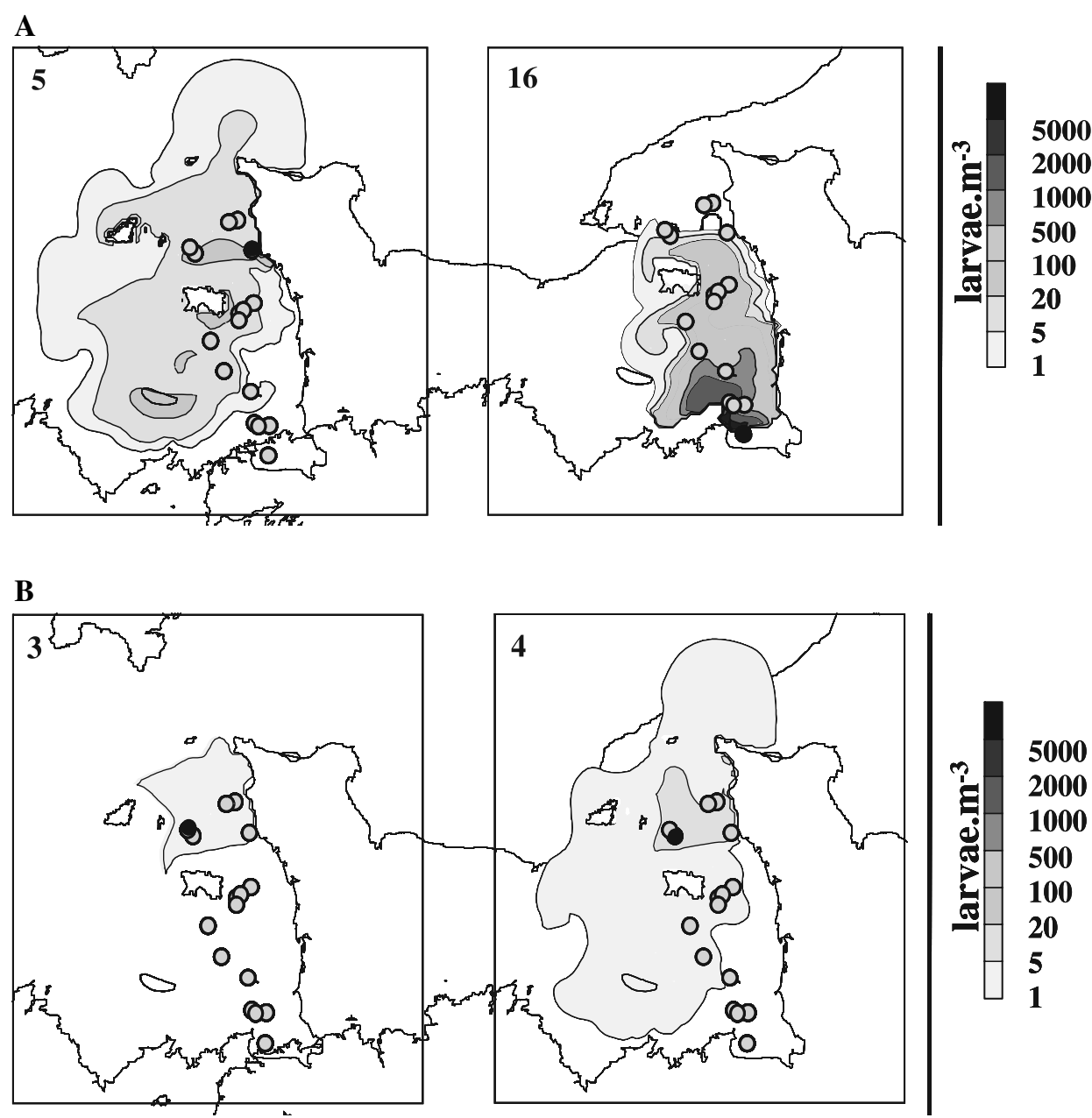

Japanese oysters. During a survey made in 1995-1997, Blanchard and Ehrhold (1999) reported the occurrence of the slipper limpet at very high densities in this bay and noted its presence at more northern and western locations where it was not described 20 years before (e.g. Chausey islands). The genetic analysis highlighted that, whatever the true age of the populations and regardless of their locations and local density, levels of allelic richness and gene diversity were generally very high. For example, a high level of genetic diversity was found in populations 1-4 sampled in low-density areas (Fig. 1). As expected with microsatellite loci, genetic diversity estimates were much higher than those observed with enzymatic loci in a previous study of $C$. fornicata (Dupont et al. 2003) and were similar to those observed with microsatellite loci in other marine invertebrates with a planktonic larval phase (e.g. Pectinaria koreni; Jolly et al. 2003). All populations deviated from Hardy-Weinberg equilibrium; a pattern likely to be due to fine-grained spatial or temporal Walhund effect as observed in other marine invertebrates (David et al. 1997) rather than to recurrent inbreeding or null alleles (Dupont and Viard 2003). In addition, our genetic analysis showed that there is a very weak barrier to gene flow as observed in other studies of regional gene flow in marine invertebrates with planktonic larvae [e.g. zebra mussel (Astanei et al. 2005); P. koreni (Jolly et al. 2003)]. In particular, populations located more than $100 \mathrm{~km}$ apart (e.g. populations from group A and group C in Fig. 1) did not show significant genetic differentiation.

Invaders generally colonize new territories via one or few founding populations. Founder effects are usually accompanied by low genetic diversity and strong genetic structure (Hanski and Simberloff 1997; Shigesada and Kawasaki 1997). However, C. fornicata did not exhibit founder effects. In particular, we demonstrated a high degree of connectivity between populations in the SMG, a pattern in agreement with the review by Kinlan and Gaines (2003), on propagule dispersal ability, in which the highest genetic dispersal estimates (mean $=100 \mathrm{~km}$ ) were found in marine invertebrates with a feeding planktonic stage. Our results also complement the increasing number of genetic studies showing that populations of successful invaders are characterized by high population genetic diversity - e.g. Holland (2001), Kolbe et al. (2004) but see Voisin et al. (2005) who documented 
contrasting genetic patterns according to the vectors of introductions.

From genetic data to larval-dispersal simulation

The above conclusions relied on genetic estimates of dispersal distance which are long-term average of effective dispersal and include historical effects (Slatkin 1985; Slatkin and Barton 1989). To gain insight on the scheme of contemporary dispersal and to examine if larval dispersal alone could explain the connectivity between populations, we used a simulation model for estimating larval dispersal constrained by oceanographic features. This model supported the interpretation of genetic data: (1) high-density populations are able to release a large number of larvae to neighbouring populations, a result well correlated to the large genetic diversity observed in populations and (2) larvae can disperse over very long distances within a short-time period (21 days), highlighting the potential for high gene flow through larval dispersal.

Considering the large number of larvae that can be continuously released during the 6-month breeding period of $C$. fornicata in France (Dupouy and Latrouite 1979; Deslous-Paoli 1985), an even larger degree of larval exchanges than shown by the model is likely to occur in the field and to erase in a few generations any pattern of founder effects or genetic isolation by geographic distance. Population 6 was genetically differentiated with the other SMG populations, a situation not explained by the model and that could be due to a recent founder event from a genetically differentiated source population (compared to the other SMG populations). The larval dispersal model suggests that genetic differentiation of population 6 will be rapidly erased; temporal genetic monitoring of this population would allow us to test this hypothesis.

Reduced current flow or eddies may alter patterns of within- and among-species diversity (see Smith and Witman 1999). Our simulations showed that the large current eddies in the SMG do not appear as a major force modifying larval exchanges between populations of $C$. fornicata. However, the simulation model supplied only a qualitative picture of instantaneous dispersal. Quantitative estimates of contemporary larval exchanges would require a more complex model including possibility for vertical migration of larvae (3D model), realistic climatic sequences over the full duration of the breeding season and mortality rates for larvae during the transportations. As highlighted by Kinlan and Gaines (2003), models of larval transport coupled with genetic and chemical tagging methods can provide realistic scenarios for understanding dynamics of marine ecosystems. Modelling coupled with tagging methods could be of special interest in invasion biology studies to decipher various mechanisms responsible for the spread of an exotic species.
Conclusion: invasion success and larval dispersal

Many factors act in synergy and contribute to the success of $C$. fornicata in its introduced range: a long-lived free-swimming stage (Coe 1949 this study), chemical attraction of larvae by adults (McGee and Targett 1989), ability of the species to create its own substrata (Ehrhold et al. 1998), human-mediated transportation (Blanchard 1997) that contribute to initiate new population nuclei and new relay populations between already existing populations. Based on these features and our data, we suggest that primary populations established in the SMG rapidly reached high densities because of recurrent introductions, large reproductive success and gregariousness behaviour of larvae. Any genetic differences that might have occurred among newly established populations could then have been quickly erased by the large flow of larvae released from high-density populations.

Our study shows that the management policy against $C$. fornicata invasion needs to start from the very beginning of its introduction (see also Myers et al. 2000; Frankham 2005), and to include larvae as part of the management scheme. The limits to dispersal in $C$. fornicata are still nevertheless to be determined. From our model, it is likely that larvae from northern populations of the SMG are transported to the eastern part of the Contentin Peninsula, contrary to what was supposed in our previous work (Dupont et al. 2003). This question should be addressed on a broader scale analysis that includes several populations from each of the bays of the English Channel.

Acknowledgments The authors wish to express their gratitude to the crew of the RV "Côte de la Manche" and participants in the BENTHOMONT cruise for sampling, to Thierry Comtet for stimulating discussions and Carolyn Engel for comments and editing of the manuscript. This project was funded by the PNECSite Atelier "Baie du Mont St Michel" and the INVABIO program of the Ministère de l'Ecologie et du Développement Durable (project no. D4E/SRP/01115). Additional supports for genotyping came from the European Network of Excellence "Marine Genomics" (contract $\mathrm{n}^{\circ}$ 505403). FV acknowledges the support by the MarBEF Network of Excellence "Marine Biodiversity and Ecosystem Functioning" which is funded in the Community's Sixth Framework Programme (contract no. GOCE-CT-2003-505446). This publication is contribution number MPS-06010 of MarBEF. LD acknowledges the Region Bretagne for her $\mathrm{PhD}$ grant. The experiments and methods used in this study comply with the current laws in France.

\section{References}

Astanei I, Gosling E, Wilson JC, Powell E (2005) Genetic variability and phylogeography of the invasive zebra mussel, Dreissena polymorpha. Mol Ecol 14:1655-1666

Belkhir K, Borsa P, Goudet J, Chiki L, Bonhomme F (1996) GENETIX, logiciel sous Windows pour la génétique des populations. Laboratoire Génome, Populations, Interactions CNRS UMR 5000, Université de Montpellier II, Montpellier (France)

Blanchard M (1997) Spread of the slipper limpet Crepidula fornicata (L. 1758) in Europe: current state and consequences. Sci Mar 61:109-118 
Blanchard M, Ehrhold A (1999) Cartographie et évaluation du stock de crépidules (Crepidula fornicata L.) en baie du Mont Saint-Michel. Haliotis 28:11-20

Borsa P, Jarne P, Belkhir K, Bonhomme F (1994) Genetic structure of the palourde Ruditapes decussatus L. in the Mediterranean. In: Beaumont AR (ed) Genetics and evolution of aquatic organisms. Chapman \& Hall, London, pp 103-113

Coe WR (1949) Divergent methods of development in morphologically similar species of prosobranch gastropods. J Morph 84:383-399

Cornuet JM, Luikart G (1996) Description and power analysis of two tests for detecting recent population bottlenecks from allele frequency data. Genetics 144:2001-2014

David P, Perdieu M-A, Pernot A-F, Jarne P (1997) Fine-grained spatial and temporal population genetic structure in the marine bivalve Spisula ovalis. Evolution 51:1318-1322

Deslous-Paoli JM (1985) Crepidula fornicata L. (gastéropode) dans le bassin de Marennes-Oléron: structure, dynamique et production d'une population. Oceanol Acta 8:453-460

Dupont L, Viard F (2003) Isolation and characterization of highly polymorphic microsatellite markers from the marine invasive species Crepidula fornicata (Gastropoda: Calyptraeidae). Mol Ecol Notes 3:498-500

Dupont L, Jollivet D, Viard F (2003) High genetic diversity and ephemeral drift effects in a recent and successful introduced mollusc (Crepidula fornicata: Gastropoda). Mar Ecol Prog Ser 253:183-195

Dupouy H, Latrouite D (1979) Le développement de la crépidule sur le gisement de la coquille Saint-Jacques de la baie de SaintBrieuc. Sci Pêch 292:13-19

Ehrhold A, Blanchard M, Auffret J-P, Garlan T (1998) The role of Crepidula proliferation in the modification of the sedimentary tidal environment in Mont-Saint-Michel Bay (The Channel, France). C R Acad Sci Paris Sci Terre Planètes 327:583-588

Ellien C, Thiébaut E, Barnay A, Dauvin J-C, Gentil F, Salomon JC (2000) The influence of variability in larval dispersal on the dynamics of a marine metapopulation in the Eastern Channel. Oceanol Acta 23:423-442

Ellien C, Thiébaut E, Dumas F, Salomon JC, Nival P (2004) A modelling study of the respective role of hydrodynamic processes and larval mortality on larval dispersal and recruitment of benthic invertebrates: example of Pectinaria koreni (Annelida: Polychaeta) in the Bay of Seine (English Channel). J Plank Res 26:117-132

El-Mousadik A, Petit RJ (1996) High level of genetic differentiation for allelic richness among populations of argan tree (Argania spinosa (L.) Skeels) endemic to Morocco. Theor Appl Genet 92:832-839

Frankham R (2005) Resolving the genetic paradox in invasive species. Heredity $94: 385$

Goudet J (1999) FSTAT vers. 2.8, updated from Goudet (1995). Fstat: a computer program to calculate F-statistics. J Hered $86: 485-486$

Goudet J, Raymond M, De Meeüs T, Rousset F (1996) Testing differentiation in diploid populations. Genetics 144:1933-1940

Goulletquer P, Bachelet G, Sauriau PG, Noel P (2002) Open Atlantic coast of Europe - a century of introduced species into French waters. In: Leppäkoski E, Gollash S, Olenin S (eds) Invasive species of Europe - distribution, impact and management. Kluwer Academic Publishers, Dordrecht, pp 276-290

Hanski I, Simberloff D (1997) The metapopulation approach, its history, conceptual domain and application to conservation. In: Hanski IA, Gilpin ME (eds) Metapopulation biology. Academic, San Diego, pp 5-26

Hoagland KE (1978) Protandry and the evolution of environmentally-mediated sex change: a study of the mollusca. Malacologia 17:365-391

Holland BS (2001) Invasion without a bottleneck: microsatellite variation in natural and invasive populations of the brown mussel Perna perna (L). Mar Biotechnol 3:407-415
Jolly MT, Viard F, Weinmayr G, Gentil F, Thiébaut E, Jollivet D (2003) Does the genetic structure of Pectinaria koreni (Polychaeta: Pectinariidae) conform to a source-sink metapopulation model at the scale of the Seine Basin? Helgol Mar Res 56:238246

Kinlan BP, Gaines SD (2003) Propagule dispersal in marine and terrestrial environments: a community perspective. Ecology 84:2007-2020

Kolbe JJ, Glor RE, Rodriguez Schettino L, Chamizo Lara A, Losos JB (2004) Genetic variation increases during biological invasion by a Cuban lizard. Nature 431:177-181

Kyle CJ, Boulding EG (2000) Comparative population structure of marine gastropods (Littorina spp.) with and without pelagic larval dispersal. Mar Biol 137: 835-845

McGee BL, Targett NM (1989) Larval habitat selection in Crepidula (L.) and its effect on adult distribution patterns. J Exp Mar Biol Ecol 131:195-214

Myers JH, Simberloff D, Kuris AM, Carey JR (2000) Eradication revisited: dealing with exotic species. Trends Ecol Evol 1 $15: 316-320$

Orbi A, Salomon JC (1988) Dynamique de marée dans le golfe normano-breton. Oceanol Acta 11:55-64

Pechenik JA (1999) On the advantages and disadvantages of larval stages in benthic marine invertebrate life cycles. Mar Ecol Prog Ser 177:269-297

Pogson GH, Taggart CT, Mesa KA, Boutilier RG (2001) Isolation by distance in the Atlantic cod, Gabus morhua, at large and small geographic scales. Evolution 55:131-146

Poulin E, Palma AT, Leiva G, Narvaez D, Pacheco R, Navarrette SA, Castilla JC (2002) Avoiding offshore transport of competent larvae during upwelling events: the case of the gastropod Concholepas concholepas in Central Chile. Limnol Oceanogr 47:1248-1255

Raymond M, Rousset F (1995) GENEPOP (version 1.2): population genetics software for exact tests and ecumenicism. J Hered $86: 248-249$

Sakai AK, Allendorf FW, Holt JS, Lodge DM, Molofsky J, With KA, Baughman S, Cabin RJ, Cohen JE, Ellstrand NC, McCauley DE, O'Neil P, Parker IM, Thompson JN, Weller SG (2001) The population biology of invasive species. Ann Rev Ecol Syst 32:305-332

Salomon JC, Breton M (1991) Courants résiduels de marée dans la Manche. Oceanol Acta sp 11:47-53

Sax DF, Brown JH (2000) The paradox of invasion. Glob Ecol Biogeogr 9:363-371

Shigesada N, Kawasaki K (1997) Biological invasions: theory and practice. Oxford University Press, Oxford

Slatkin M (1985) Gene flow in natural populations. Ann Rev Ecol Syst 16:393-430

Slatkin M, Barton NH (1989) A comparison of three indirect methods for estimating average levels of gene flow. Evolution 43:1349-1368

Smith F, Witman JD (1999) Species diversity in subtidal landscapes: maintenance by physical processes and larval recruitment. Ecology 80:51-69

Swearer SE, Shima JS, Hellberg ME, Thorrold SR, Jones GP, Robertson DR, Morgan SG, Selkoe KA, Ruiz GM, Warner RR (2002) Evidence of self-recruitment in demersal marine populations. Bull Mar Sci 70:251-271

Thieltges DW, Strasser M, Reise K (2003) The American slipper limpet Crepidula fornicata (L.) in the northern Wadden Sea 70 years after its introduction. Helgol Mar Res 57:27-33

Thorrold SR, Jones GP, Hellberg ME, Burton RS, Swearer SE, Neigel JE, Morgan SG, Warner RR (2002) Quantifying larval retention and connectivity in marine populations with artificial and natural markers. Bull Mar Sci 70:291308

Toonen RJ, Pawlik JR (2001) Foundations of gregariousness: a dispersal polymorphism among the planktonic larvae of a marine invertebrate. Evolution 55:2439-2454 
Voisin M, Engel C, Viard F (2005) Differential shuffling of native genetic diversity across introduced region in a brown alga: aquaculture vs. maritime traffic effects. Proc Natl Acad Sci USA 102:5432-5437

Weir BS, Cockerham CC (1984) Estimating F-statistics for the analysis of population structure. Evolution 38:1358-1370

Williamson M (1996) Biological invasions. Chapman \& Hall, London
Wolff WJ, Reise K (2002) Oyster imports as a vector for the introduction of alien species into northern and western European coastal waters. In: Leppäkoski E, Gollash S, Olenin S (eds) Invasive species of Europe-Distribution, impact and management. Kluwer Academic Publishers, Dordrecht, pp 193 205 